12:439-442.

12. Smith PW, Rusnak PG. APIC guideline for infection prevention and control in the long-term care facility. Am J Infect Control 1991;19:196-215.

13. Satterfield N. Infection control in long-term care facilities: the hospital-based practitioner's role. Infect Control Hosp Epidemiol 1993;14:40-47.

14. Cohen ED, Hierholzer WJ, Schilling CR, Snydman DR Nosocomial infections in skilled nursing facilities: a preliminary survey. Public Health Rep 1979;94:162-165.

15. Magnussen MH, Robb SS. Nosocomial infections in a longterm care facility. Am J Infect Control 1980;8:12-17.

16. Garibaldi RA, Brodine S, Matsumiya S. Infections among patients in nursing homes. Policies, prevalence, and problems. N Engl J Med 1981;305:731-735.

17. Gambert SR, Duthie EH, Priffer B, Rabinovitch RA. Bacterial infections in a hospital-based skilled nursing facility. J Chron Dis 1982;35:781-786.

18. Farber BR, Brennen C, Puntereri AJ, Brody J. A prospective study of nosocomial infections in a chronic care facility. $J \mathrm{Am}$ Geriatr Soc 1984;32:499-502.

19. Nicolle LE, McIntyre M, Zacharias H, MacDonell JA. Twelvemonth surveillance of infections in institutionalized elderly men. J Am Geriatr Soc 1984;32:513-519.

20. Standfast SJ, Michelsen PB, Baltch AL, et al. A prevalence survey of infections in a combined acute- and long-term care hospital. Infect Control 1984;5:177-184.

21. Jackson MM, Fierer J. Infections and infection risk in residents of long-term care facilities: a review of the literature 1970-1984. Am J Infect Control 1985;13:63-77.

22. Setia U, Serventi I, Lorenz P. Nosocomial infections among patients in a long-term care facility: spectrum, prevalence, and risk factors. Am J Infect Control 1985;13:57-62.

23. Franson TR, Duthie EH, Cooper JE, van Oudenhoven G, Hoffmann RG. Prevalence survey of infections and their predisposing factors at a hospital-based nursing home care unit. $J$ Am Geriatr Soc 1986;34:95-100.

24. Vlahov D, Tenney JH, Cervino KW, et al. Routine surveillance for infections in nursing homes: experience at two facilities. $\mathrm{Am}$ J Infect Control 1987;15:47-53.

25. Alvarez S, Shell CG, Woolley TW, Berk SL, Smith JK.
Nosocomial infections in long-term care facilities. $J$ Gerontol 1988;43:M9-17.

26. Jacobson C, Strausbaugh LJ. Incidence and impact of infection in a nursing home care unit. Am J Infect Control 1990;18:151-159.

27. Darnowski SH, Gordon M, Simor AE. Two years of infection surveillance in a geriatric long-term care facility. Am I Infect Control 1991;19:185-190.

28. Michel J-P, Lesourd B, Conne P, Richard D, Rapin C-H. Prevalence of infections and their risk factors in geriatric institutions: a one-day multicentre survey. Bull World Health Organ 1991;69:35-41.

29. Magaziner J, Tenney JH, DeForge B, Helbel JR, Muncie HL, Warren JW. Prevalence and characteristics of nursing homeacquired infections in the aged. $\mathrm{J} \mathrm{Am}$ Geriatr Soc 1991;39:1071-1078.

30. Steinmiller AM, Robb SS, Muder RR. Prevalence of nosocomial infection in long-term care Veterans Administration medical centers. Am J Infect Control 1991;19:143-146.

31. Beck-Sague C, Banerjee S, Jarvis WR. Infectious diseases and mortality among US nursing home residents. Am J Public Health 1993;83:1739-1742.

32. Smith PW. Infection control in nursing homes. JAMA 1985;254:2951-2952.

33. Bentley DW. Current challenges and future opportunities. Infect Control Hosp Epidemiol 1989;10:481-483.

34. Childress JA, Childress JD. Statistical test for possible infection outbreaks. Infect Control 1981;2:247-249.

35. Garner JS, Jarvis WR, Emori TG, Horan TC, Hughes JM. CDC definitions for nosocomial infections, 1988. Am J Infect Control 1988;16:128-140.

36. McGeer A, Campbell B, Emori TG, et al. Definitions of infection for surveillance in long-term care facilities. Am J Infect Control 1991;19:1-7.

37. Rusnak PG, Horning LA. Surveillance in the long-term care facility. In: Smith PW, ed. Infection Control in Long-Term Care Facilities. 2nd ed. Albany, NY: Delmar Publishers, Inc; 1994:117-126.

38. Lewis SM. The effect of surveillance definitions on nosocomial urinary tract infection rates in a rehabilitation hospital. Infect Control Hosp Epidemiol 1995;16:43-48.

\title{
DOT Exempts Cultures and Stocks From Strict Packaging
}

\section{by Gina Pugliese, RN, MS Medical News Editor}

The Department of Transportation (DOT) granted an emergency temporary exemption to the strict packaging requirements for cultures and stocks of infectious substances that were to go into effect on January 1, 1996, under the final Hazardous Materials (HM) $181 \mathrm{G}$ rule for infectious substances (formerly called etiologic agents). This emergency exemption expires on April 15, 1996, and was issued to Browning-Ferris Industries Medical Waste Systems (BFI) of Houston, Texas. Cultures and stocks will be allowed to be packaged as regulated medical waste according to provisions of 49 CFR 173.134 and 173.197.

In its request for an exemption, BFI cited the DOT packaging requirements as burdensome and estimated that the cost may be as high as $\$ 20,000$ per month for one hospital to specially package their discarded cultures and stocks for transport offsite. This exemption also was granted to members of the Medical Waste Institute and persons represented by the American Clinical Laboratory Association.

In actual practice, nothing has changed. The exemption was effec- tive December 22, 1995, and the DOT's final rule that expanded the definition of "infectious substances" to include cultures and stocks was not effective until January 1, 1996.

It is expected that all companies involved in transport of medical waste will file for a similar exemption. Medical waste experts say that DOT probably will take steps to expand this exemption beyond a temporary status.

From: Department of Transportation, Research and Special Program Administration. Emergency Exemption Document (DOT-E 11588); December 22, 1995. 